\begin{tabular}{|c|c|}
\hline 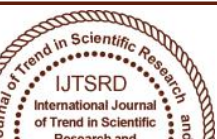 & $\begin{array}{l}\text { International Journal of Trend in Scientific Research and Development (IJTSRD) } \\
\text { International Open Access Journal | www.ijtsrd.com }\end{array}$ \\
\hline a & ISSN No: 2456 - 6470 | Volume - 3 | Issue - 1 | Nov - Dec 2018 \\
\hline
\end{tabular}

\title{
Understanding Learner Type and their Preferences Towards the Utilisation of Computer Related Learning Facilities in the North and South West Regions of Cameroon
}

\author{
Neba Dorine Ngum Ph.D \\ Department of Curriculum Studies and Teaching (CST), \\ Faculty of Education, University of Buea, Cameroon
}

\begin{abstract}
This study investigated the attitude of different types of learners towards the use of computer related learning facilities in the North West and South West Regions of Cameroon. It was designed to respond to this research question: Do slower learners have a different attitude towards the use of computer related learning facilities from faster learners? The sample consisted of 1353 students from 18 schools. These schools were randomly selected from 35 schools with computer laboratories and internet facilities in the North West and South West Regions of Cameroon. The research instrument used was a student questionnaire. The data collected were subjected to descriptive and inferential statistical analysis, using the Statistical Package for the Social Sciences (SPSS). The finding of the study was that slower learners have a less positive attitude towards the use of computerrelated learning facilities than faster learners. On the basis of the findings, recommendations for enhancing students' attitude towards the use of computer-related learning facilities were made for education policy development and for teaching.
\end{abstract}

Key Words: Learner Type, Preferences, Computer Related Learning Facilities

\section{INTRODUCTION}

The use of the computer in education reflects and responds to present and future needs of people functioning in an intensely changing and challenging environment. The computer is very important for providing opportunities for students to learn to operate in an information age. The use of computer related learning facilities has become one of the basic building blocks of modern education. Many countries now regard the understanding and mastery of computer basic skills and concepts as part of the core of education, alongside reading, writing and numeracy. International organisations are also promoting their use in schools. For example, UNESCO aims to ensure that all countries both developed and developing have access to the best educational facilities necessary to prepare young people to play full roles in modern society (UNESCO, 2002: 9). Because of the fundamental importance of computer related learning facilities in the task of schools today, UNESCO has publications on helping member states. Some of these publications include "Informatics for Secondary Education: A Curriculum for Schools" (1998). "Informatics for Primary Education" (2000).

The use of computer related learning facilities opens new doors for education. Many people now learn via self-paced, interactive, computer-based courses (Long, 2003, p.27). Development, according to Nwagwu (2006), is partly determined by the ability to establish a synergistic interaction between technological innovation and human values. Since the mid $20^{\text {th }}$ century, the use of computer related learning facilities has developed at a rate that gives it a strong role in development and globalization. According to Brakel and Chisenga (2003), these facilities have a significant impact on all areas of human activity.

Yusuf (2005) says that the field of education has been affected by computer related learning facilities, which have undoubtedly affected teaching, learning and research. These facilities have the potential to accelerate, enrich, and deepen skills, to motivate and engage students to help relate school experience to work practices, create economic viability for 
tomorrow's workers, as well as strengthening teaching and helping schools change. The use of computer related learning facilities has many benefits. According to Capel, Leask and Turner (2001), the benefits of integr ting these facilities into the teaching and learning process are many. Learning is stimulated, difficult ideas are made more understandable, students are given the power to try different ideas and to take risks, analytical and divergent thinking is encouraged. The use of these facilities makes teachers take a fresh look at how they teach and the ways in which students learn. Students make more effective use of computers if teachers know how and when to intervene computers.

According to Alessi and Trollip (2001), with computer based instruction, learning takes less time, lesson materials are handed out easily and cheaply. Students work at their own pace and convenience. They are also offered the opportunity for extensive practice, through which their motivation is stimulated. The ability to access and use computer related learning facilities is no longer a luxury but has become indispensable in almost all domains of life. Student use of these facilities prepares them to face challenges in further education and professional life.

According to Mbangwana (2008 p.3), in 1995 when the educational experts met in Yaounde to discuss how the educational system could be improved upon, nothing was mentioned about the use of computer related learning facilities in the classroom. The Cameroon education law 9/004 of 14 April 1998 does not make mention of the use of computers in the school system. Teacher training colleges are only now making provision for teaching computer use for pedagogic purposes. This implies that the teaching core is to a great extent computer illiterate.

The use of computers in Cameroon secondary schools was formally introduced in 2001. In his February 2001 message to the youths, the President of Cameroon called for the embracing of the knowledge economy (Cameroon, 2007 p.3). In preparation, he promised the introduction of computers in schools and the endowment of computer rooms to schools. There was the impact of that presidential speech in 2002 with the introduction of computer related learning facilities in secondary general and technical schools. Numerous schools have benefited from presidential "gifts" of multimedia centres connected to the internet.
Officially programmes of ICT were designed official programmes of ICT were designed for secondary schools in 2003. (ERNWACA-Cameroon, 2005:11). The Ministry of Secondary Education developed a strategy for the implementation of national ICT policy in Basic Education over 2007-2015. The strategy included the training in ICT for teachers and school directors and integration of ICT into the curriculum (Cameroon 2007(a): 21-24). It also drafted national guidelines for teaching ICT in pre-school and primary schools, with six different modules adapted to each level, from discovery and presentation skills to applying skills to knowledge construction and finally learning health and safety issues related to the use of ICT. The teacher modules included productivity and research, applying ICT to teaching and learning, evaluation, and lastly, social, moral and human questions related to ethics and equality (Cameroon, 2007a).

These efforts have led to some moves from traditional pedagogical and administrative culture, moves from teacher-centred pedagogies and memorization as a learning technique to a more constructivist, pupilcentred approach, with pupils assuming more responsibility because of increased development of research and problem solving skills through the use of ICT (ERNWACA - Cameroon, 2005:11). Computer science is a compulsory subject for all the students of the GCE Ordinary Level.

\section{SITUATING THE CONTEXT OF THE RESEARCH PROBLEM}

The world is advancing rapidly in technology. As technology continues to advance, computers are becoming more a part of everyday life. It is generally felt that computer literacy is vital to success in today's world. Within the field of education over the last decades, a gradual but significant shift has taken place, resulting in less emphasis on teachers and teaching and greater stress on learners and learning. The gradual change from a teacher- centred to a learner-centred education system the world over is contributing to the increasing use of computers in education.

Computer use encourages self-directed learning. Selfdirected learning according to Petty (2004) is a humanistic approach in which the teacher takes on a facilitating role. It gives control and responsibility for learning to the learners. The ability to learn by oneself is the greatest gift any teacher can give a learner; 
indeed it is the ultimate aim of education. Selfdirected learning has many advantages. It encourages active learning, develops student autonomy, and gives the responsibility for learning to the student (Petty, 2004,). According to this author, the educational gains for self-directed learning are the same as for independent learning

$>$ It reduces the pace and pressure of teaching, thus enabling the teacher to deal with difficult material more slowly, and increases the proportion of time spent active, student-centred activities.

$>$ It increases motivation. The coaching involved encourages students to take full responsibility for their own learning, challenges passive to learning, and teaches the active learners' coping strategy and mind-set.

$>$ Students develop independent learning skills and attitudes which are of vital importance for educational development and progress.

$>$ Students can learn at their own pace, and in a manner which suits their own preferences and learning style.

$>$ It is a change, and students very much enjoy it. It becomes a preferred learning method.

$>$ It can encourage "deep" rather than "surface" learning if assessments focus on understanding.

$>$ Students discover they can without a teacher (Petty, 2004).

There are many other advantages of the use of computers. Computers lead to interactive learning. When using the computer, students can work at their own pace, learning can take place anywhere, anytime, via communication links to available resources. Computers, according to Shelly, Cashman and Vermaat (2002) have the advantages of speed, reliability, consistency, storage and communication. Williams (2000) tells us that students who use computers achieve better results in communications, cooperation and problems-solving than students who do not use the computer. The use of computers also broadens the horizons of young people. Mikropoulos (2003) is of the pinion that the use of computers supports the improvement of pupils' mental and creative activities. Wheeler (2000) says that creative use of computers in education can increase creative thinking. Computers are looked upon as tools for increasing efficiency and productivity in the curriculum. Another advantage of the computer use is that learning is focused on problem solving. It leads to the increased motivation of learners. . According to Allessi and Trollip (2001), students work at their own pace and convenience. Students are also offered the opportunity for extensive practice, through which their motivation is stimulated.

According to Capel et al (2001, p. 41), interactive technology motivates and stimulates learning. Difficult ideas are made more understanding when computer facilities make them visible. These facilities give students the power to try out different ideas and to take risks. If students do not use computer learning facilities, they would not be able to pursue education at their own pace; self- directed learning would not be encouraged; learning will only take place within the confines of a classroom. Students will not be able to achieve expected results in communication, cooperation and in solving problems. The horizons of young people will not be broadening. Their mental and creative activities will not be improved upon. There will be no creative thinking. There will be no efficiency and productivity in the curriculum.

Although the use of computers has all these advantages, there are some problems associated with learning through computer assisted facilities. Some of these problems include lack of computer operational skills, lack of competent teachers, technology related phobia. According to Mattson (2006, p, 45) the conditions hampering the use of computers in Africa are well documented and include:

> Unavailable or inadequate, unreliable, expensive electricity and tele communication and limited bandwidths across the region, with poor "teledensity" in rural areas.

Weak policy environment for improving infrastructure, unregulated privatization and corruption in the telecommunication sector, and high taxation of ICT products and services as a luxury.

Lack of skills, training and awareness of ICTs even where they are available, they are often under-utilised due to lack of understanding and technical support.

Several studies have identified a range of factors as barriers to integrating computer technology in the curriculum. According to Bingimlas (2009), these factors include lack of computers, lack of quality software, lack of time, technical problems, teachers' attitudes towards computers, poor funding, lack of teacher confidence, resistance to change, poor administrative support, lack of computer skills, poor fit with the curriculum, lack of incentives, scheduling 
difficulties, poor training opportunities, and lack of skills on how to integrate computers in education.

In spite of these problems, the use of computer assisted technology can be facilitated by a positive attitude and inhibited by a negative attitude of the students. Thus the attitudes of students towards the computer in this computer world matters a lot. If students are to adopt computer technologies, they must have the right attitude towards computers. It is therefore very important to assess students' attitude in order to know where it is negative and where it is positive. This view is supported by Sam, Othman and Nordin (2005). According to these authors, researchers have proposed that attitudes towards the use of the computer could be an important factor in helping people learn computer skills and use the computers. Monitoring the user's attitudes toward the computers should be a continuous process if the computer is to be used effectively as a teaching and learning tool. In this connection, the problem for this study is to ascertain the attitude of learner type towards the use of computer related learning facilities in Cameroon schools. In other words, do learners' attitudes towards the use of computer related learning facilities differ with the type of learner involved?

\section{OBJECTIVE OF THE STUDY}

The objective of this study was to find out if slower learners have different attitude towards the use of computer related learning facilities from faster learners.

\section{RESEARCH QUESTION}

Do slower learners have a different attitude towards the use of computer related learning facilities from faster learners?

\section{HYPOTHESES OF THE STUDY}

$\mathrm{HO}_{4}$ : There is no significant difference between slower learners and faster learners in attitude towards the use of computer related learning facilities.

Ha4: There is a significant difference between slower learners and faster learners in attitude towards the use of computer related learning facilities.

\section{REVIEW OF RELATED LITERATURE}

Some concepts which have some implications for the study were reviewed.

\section{Uses of Computers in Education}

Singh (2009) gives us the real life uses of computers in education. The computer is used for the teaching and learning process. In relation to instructions, students can be instructed using PowerPoint slides, word documents or Web pages and using hyperlinks for better concept clarity. Computers help in improving pronunciation of students by using microphones, headphones, speakers, specially prepared software and special dedicated websites. Video conferencing, chat and email helps in better communication, hence better concept clarity. Also concept of E-tutor has given access to teachers instantly and given teachers a better chance to earn. Current syllabus can be viewed through web site of the concerned school board; made available to students if teacher has made a website and uploaded using Internet; and updating- using web could be done easily. Computers can also be used in inspiring students to express their imagination using Paint Brush, encouraging the students to surf web pages and gather relevant detailed information through web pages. Readymade software could give practice material to students.

In relation to learning, computers are used in collecting notes, pictures, videos from web pages for detailed information and projects/assignments. They are used in saving the documents as soft copy for future use. Computers are also used in learning through animations, as they are much near to the students. They are also used for E-books, online libraries, online encyclopaedias which help to guide in minutes and save precious time and resources. Videos are created using images, albums for better power point slides. Simulated learning gives them an idea of the real situation. They are also used for publication of pamphlet, brochures for awareness with institution and among community members.

Computers are also used for testing and evaluation process. They are used for keeping records of students for their academic scores; keeping records in relation to personal history; creating question bank for students. Computers are also used for testing by asking questions from question bank, online testing and evaluation. They are used for analysis and interpretation of the data, for previous year question papers and sample papers using web sites.

Another use of computers is for guidance purposes. Collective records of the students maintained yearwise are stored in computers. There is testing for aptitude, interest, psychology using computer data bases and internet. 
Library: Using computers, documents are stored as soft copy for students, faculty members us. Online magazines, journals, brochures, research articles. Records of the books maintained using special library software. Computers are used for records of students(personal, academic, financial); records of employees of school; accounts of the institution; decision making process; aid to memory with minimum paper work; eye on current regulations of government and affiliating school boards and related authorities . Computers are also used for school canteen for billing; fees collection and maintenance of fees record; circulation of instruction, notices and getting it in printed form.

Pillai (2011) also gives us some uses of the computer. It can also be used for word processing; word processing software automatically corrects spelling and grammar mistakes. If the content of a document repeats one doesn't have to type it each time. One can use the copy and paste features. One can printout documents and makes several copies. It is easier to read a word-processed document than a handwritten one. One can add images to ones document.

The computer is also used for internet. The internet is a network of almost all the computers in the world. One can browse through much more information than you could do in a library. That is because computers can store enormous amounts of information. One can also have very fast and convenient access to information. Through e-mail one can communicate with a person sitting thousands of miles away in seconds. There is chat software that enables one to chat with another person on a real-time basis. Video conferencing tools are becoming readily available to the common man.

\section{Technology Impact on Learning}

An article from Us Department of Education 1995 forum (ED Report), gives us the costs and effectiveness of educational technology. According to the ED Report, "Through the use of advanced computing and telecommunications technology, learning can also be qualitatively different. The process of learning in the classroom can become significantly richer as students have access to new and different types of information, can manipulate it on the computer through graphic displays or controlled experiments in ways never before possible, and can communicate their results and conclusions in a variety of media to their teacher, students in the next classroom, or students around the world).
According to this article, technology enhances student achievement in the following ways:

\section{Basic Skills Instruction}

$>$ Computer assisted instruction to drill

> Multi-media software - teach to a variety of learning styles

> Videodiscs - strengthen basic skills

> Video and audio technologies - bring material to life

> Distance learning - at least as effective as traditional methods of instruction

> All forms - develop new skills related to use of technology itself, necessary in workplace.

\section{Advanced Skills Instruction}

Interactive educational technologies, including:

Computer-generated simulations

Videodiscs

Internet

$>$ CD-ROM

> Students learn to: organize complex information, recognize patterns, draw inferences, communicate findings

Learn better organizational and problem-solving skills

\section{Assessment of Student Progress}

$>$ More comprehensive with multimedia

Assessments which require student's active participation

Electronic portfolios

\section{Student Motivation}

$>$ They like it better

$>$ Increased family inyolvement

Improved teachers' skills

Improved School Administration and Management

From ED Report, we are informed that successful technology-rich schools generate impressive results for students, including improved achievement; higher test scores; improved student attitude, enthusiasm, and engagement; richer classroom content; and improved student retention and job placement rates.

The effects of educational technology according to a 1994 Software Publishers' Association (SPA) study, research found that the effects of educational technology include the following:

Educational technology has a significant positive impact on achievement in all subject areas, across 
all levels of school, and in regular classrooms as well as those for special-needs students.

$>$ Educational technology has positive effects on student attitudes.

$>$ The degree of effectiveness is influenced by the student population, the instructional design, the teacher's role, how students are grouped, and the levels of student access to technology.

$>$ Technology makes instruction more studentcentred, encourages cooperative learning, and stimulated increased teacher/student interaction.

$>$ Positive changes in the learning environment evolve over time and do not occur quickly.

$>$ Software which allows young children to write and illustrate their own stories before their fine motor skills are developed enough to allow them to do so by hand.

$>$ Word processing software stimulates learners to interact more closely with their work.

$>$ Audio and video recording can give students instant feedback on their story-telling skills and can help them develop them further.

$>$ Multimedia software helps students produce multimedia reports.

$>$ Telecommunications programs link students who correspond in writing.

From the ED Report, technology is making a significant, positive impact on education. According to this report,

$>$ Educational technology has demonstrated a significant positive effect on achievement. Positive effects have been found for all major subject areas, in preschool through higher education, and for both regular education and special needs students. Evidence suggests that interactive video is especially effective when the skills and concepts to be learned have a visual component and when the software incorporates a research-based instructional design. Use of online telecommunications for collaboration across classrooms in different geographic locations has also been show to improve academic skills.

$>$ Education technology has been found to have positive effects on student attitudes toward learning and on student self-concept. Students felt more successful in school, were more motivated to learn and have increased self-confidence and selfesteem when using computer-based instruction. This was particularly true when the technology allowed learners to control their own learning.
$>$ The level of effectiveness of educational technology is influenced by the specific student population, the software design, the teacher's role, how the students are grouped, and the level of student access to the technology.

$>$ Students trained in collaborative learning, had higher self esteem and student achievement.

$>$ Introducing technology into the learning environment has been shown to make learning more student-centred, to encourage cooperative learning, and to stimulate increased teacher/student interaction.

$>$ Positive changes in the learning environment brought about by technology are more evolutionary than revolutionary. These changes occur over a period of years, as teachers become more experienced with technology.

Courses for which computer-based networks were use increased student-student and student-teacher interaction, increased student-teacher interaction with lower-performing students, and did not decrease the traditional forms of communication used. Many students who seldom participate in face-to-face class discussion become more active participants online.

Greater student cooperation and sharing and helping behaviours occurred when students used computer-based learning that had students compete against the computer rather than against each other.

Small group collaboration on computer is especially effective when student have received training in the collaborative process.

\section{Quality Learning in Using Computer Related Learning Facilities}

Computer related learning facilities enhance quality learning. According to Haddad (2001), research and experience have shown that these learning facilities well used in classrooms enhance the learning process in the following ways:

They motivate and engage students in the learning process. Students are motivated only when the learning activities are authentic, challenging, multidisciplinary, and multisensory. Video, television, and computer multimedia software can be excellent instructional aides to engage students in the learning process. In addition, sound, colour, and movement stimulate the students' sensorial apparatus and bring enjoyment to the learning process. 
They bring abstract concepts to life. Teachers have a hard time teaching, and students have a hard time learning abstract concepts, particularly when they contradict immediate intuition and common knowledge. Images, sounds, movements, animations, and stimulations may demonstrate an abstract concept in a real manner.

They foster inquiry and exploration. The inquiry process is a source of affective and intellectual enjoyment. This sense of adventure is taken away in a traditional classroom, where questions and answers are established a prior and are unrelated to students' interests, and where research is reduced to a word in the textbook. ICT have the potential to let students explore the world in cost-effective and safe ways. Video and computer animations can bring movement to static textbook lessons. Using these tools, students can initiate their own inquiry process, develop hypotheses, and then test them.

$>$ They provide opportunities for students to practice basic skills on their own time and at their own pace.

$>$ They allow students to use the information they acquired to solve problems, formulate new problems, and explain the world around them.

$>$ They provide access to worldwide information resources.

$>$ They offer the most cost-effective (and in some cases the only) means for bringing the world into the classroom.

$>$ They supply (via the Internet) students with a platform through which they can communicate with colleagues from distant places, exchange work, develop research, and function as if there were no geographical boundaries.

\section{RESEARCH METHODOLOGY}

\section{Research Design}

The design of this study is in terms of a survey of the cross-sectional variety. Frankel and Wallen (2000) defines a survey as research in which a group of people are studied by collecting and analysing data from only a few people considered to be representative of the entire group and for a cross sectional survey, information is collected at one point in time although the time it takes to collect all of the data desired may take anywhere from a day to a few weeks or more. Data were collected from respondents across the period from April 2013 to June 2013.

\section{Population of the Study}

The population of the study consisted of all the Form Five students in secondary schools with computer laboratories and internet facilities in the North West and South West Regions of Cameroon. Statistics from the Inspectorate of Pedagogy in charge of Computer Science, Regional Delegation for the South West Region - Buea (2011), gave us the list of schools with computer laboratories and internet services in the South West Region. The Inspectorate for Pedagogy in charge of Computer Science in the North West Region - Bamenda (2011), gave us the list of schools with Computer Laboratories and Internet services in the North West Region. Table 1 below summarises the information obtained from these two sources.

\section{Table 1: Enrolment of Form Five Students in Secondary Schools with Computer Laboratories and Internet Facilities in the North West and South West Regions}

\begin{tabular}{|c|c|c|c|}
\hline & $\begin{array}{c}\text { North } \\
\text { West } \\
\text { Region }\end{array}$ & $\begin{array}{c}\text { South } \\
\text { West } \\
\text { Region }\end{array}$ & Total \\
\hline Public Schools & 2728 & 3232 & 5960 \\
\hline $\begin{array}{c}\text { Denominational } \\
\text { Schools }\end{array}$ & 546 & 579 & 1125 \\
\hline $\begin{array}{c}\text { Lay Private } \\
\text { Schools }\end{array}$ & 502 & 05 & 507 \\
\hline Total & $\mathbf{3 7 7 6}$ & $\mathbf{3 8 1 6}$ & $\mathbf{7 5 9 2}$ \\
\hline
\end{tabular}

\section{Sampling Procedure}

The secondary schools involved in the study were selected through the simple random sampling technique. The lottery method through the hat-anddraw technique was used. The name of each secondary school with computer laboratory and internet facility was written on a piece of paper, squeezed and put in three different hats, one representing public secondary schools, the other representing denominational and lay private schools in the North West Region. The same procedure was repeated for secondary schools with computer laboratory and internet in the South West Region. After properly shaking the papers, the researcher pulled out at least five pieces of paper from each box. That constituted the list of secondary schools where Form Five students were involved. To get the students from the randomly selected schools, the researcher got to class and numbered the students. Those who had odd numbers were administered the 
questionnaire. In other classes those who had even numbers were administered the questionnaire.

\section{Data Collection Instrument}

The main research instrument used in this study was the student questionnaire. The questionnaire was designed for the principal respondents who were the Form Five students of some respective institutions with computer laboratories and internet facilities. The questionnaire was divided into two sections. One section focused on demographic data and the other on the attitude of students towards the use of computer related learning facilities.

The researcher carried out informal visits to some multimedia centres in the North West and South West Regions of the country. She also had informal discussions with some directors of multimedia centres, chiefs of centre as well as some Heads of Department of Computer Science in some secondary schools. Discussions with these personalities, in collaboration with the literature review, helped in the construction and validation of the student questionnaire. Schools had different computer related learning facilities. Knowledge of all these helped the researcher to come up with a questionnaire for the study.

\section{Validity of the Instrument}

Validity is an important concept in the acceptability of the use of an instrument for research purposes. The design of the questionnaire was guided by the different computer Attitude Scales available in the literature. Content and construct validity were checked. Content validity focuses on the extent to which the content of an instrument corresponds to the content of the theoretical concept it is designed to measure. Fraenkel and Wallen (2000) content that with content validity the following questions are to be considered. How appropriate is the content? How comprehensive? Does it logically get at the intended variable? How adequate does the sample of items or questions represent the content to be assessed? Is the format appropriate? The content and format must be consistent with the definition of the variable and the sample of subjects to be measured.

In this study, content validity of the questionnaire was ensured by sampling the opinions of targeted groups of persons and consulting existing literature in the area of Information and Communication Technologies. With the assistance of curriculum experts and other experts in the area of Information and Communication Technology, content validity was checked in terms of the appropriateness of the content, the comprehensiveness of the instruments, the adequacy of the sample of items or questions in representing the complete content that was intended to be measured and the appropriateness of the format of the instrument.

Specifically, the inter-judge coefficient of validity (Amin, 2005) was used to establish a Content Validity Index (CVI). Eight judges, including the two supervisors and six expert researchers in computer were used. The CVI was calculate at 0.81 higher than 0.7. The value justified the validity of the instrument. After that, the researcher gave the questionnaire to the supervisors who reviewed the process used in developing the instrument as well as the instrument itself. They made some suggestions and modifications.

\section{Reliability of the Instrument}

Ayadole (2000), comments that the reliability of a test refers to the degree of consistency and precision (accuracy) with which the test measures what it purports to measure. Reliability therefore, can be referred to as the stability, dependability and consistency of a measuring instrument. The reliability of the research instrument used in this study was tested. A pilot study was conducted in B.G.S. Molyko Buea as a pre-test of the study. There were some lapses. For example, the question which required the students to indicate their score in the Mock exams was corrected. The students thought it was score on computer Science. Some questions which were worded negatively were changed. The researcher corrected the questionnaire with the guidance of the supervisor.

\section{FINDINDS}

Quantitative research method was used in order to investigate the research problem. Students' responses to the questionnaire were statistically analyzed according to gender, type of school, subject area and type of student.

The data were analyzed using the statistical package SPSS version 17.0. Alpha level was set to test each hypothesis. Descriptive statistics, which include frequency counts and percentages on all variables, was used to indicate the level of implementation of each item. 
Table 9: Distribution of Respondents by Learner Type

\begin{tabular}{|l|c|c|}
\hline \multicolumn{1}{|c|}{ Learner Type } & Frequency & Percent \\
\hline Slow(below7) & 61 & 4.4 \\
\hline Below average(7 - 9) & 408 & 29.7 \\
\hline Average(10-11) & 308 & 22.4 \\
\hline Above average(12-15) & 310 & 22.6 \\
\hline Fast(16-20) & 285 & 20.8 \\
\hline \multicolumn{1}{|c|}{ Total } & $\mathbf{1 3 7 2}$ & $\mathbf{1 0 0 . 0}$ \\
\hline
\end{tabular}

The learners were categorised based on their general performance in the previous examination. The score was on 20. All learners who had below 7 were categorised as slow, $7-9$ as below average learners, $10-11$ as average learners, $12-15$ as above average learners and $16-20$ as fast learners.

Table 9 shows the distribution of respondents by learner type. Although the distribution of the respondents by learner type shows a relative majority (34.2\%) potential underachievers (slow and below average learners) there are significant proportions of average $(22.4 \%)$ above average $(22.6 \%)$ and fast learners $(20.8 \%)$. This implies that almost two-third $(65.8 \%)$ of the respondents range from average to fast learners. This data is presented in figure 9 below.

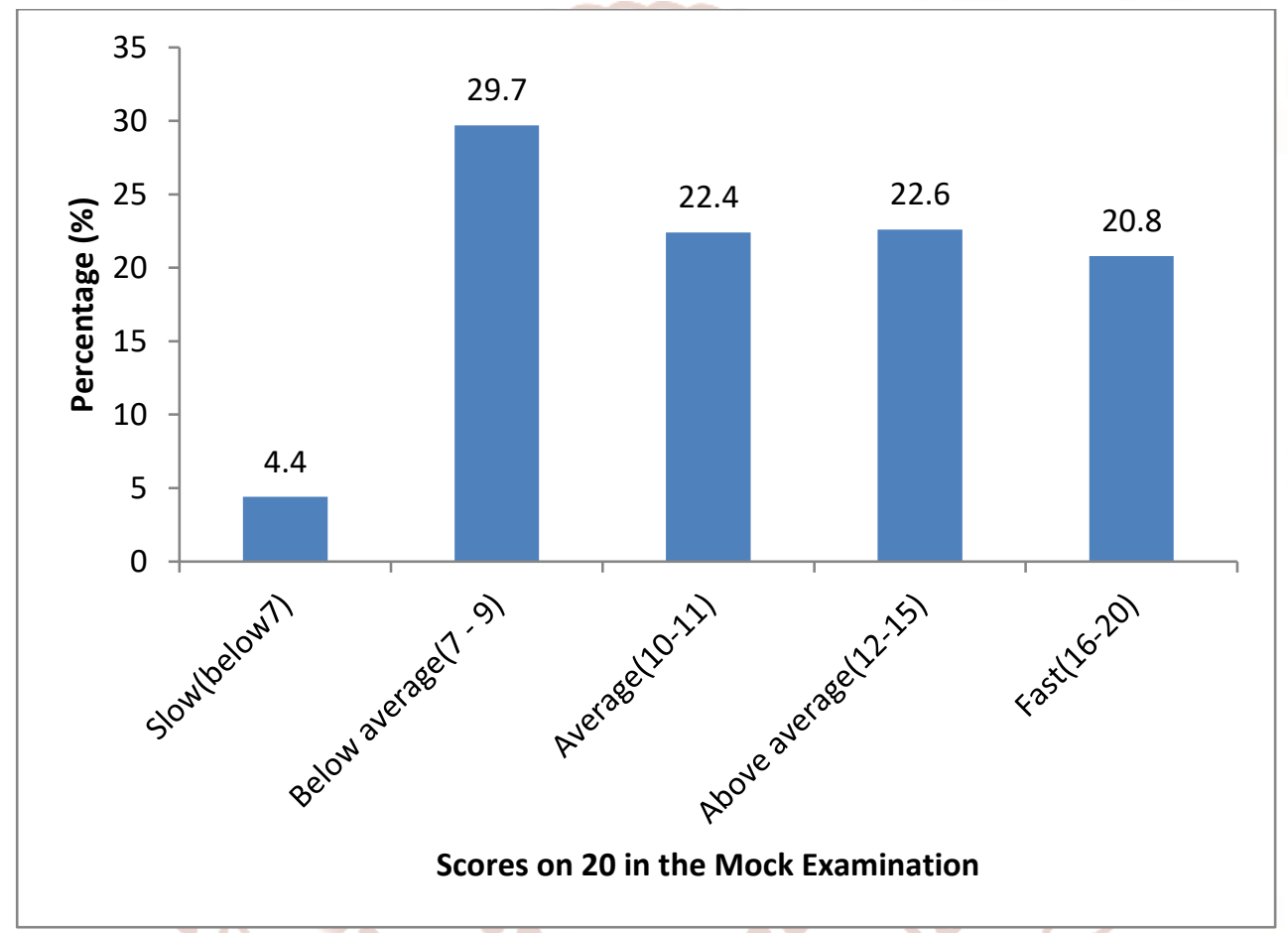

Figure 9: Distribution of Respondents by Learner Type

\section{DISCUSSION}

\section{IMPLICATIONS}

AND

EDUCATIONAL

The study sought to know if slower learners have a more or less positive attitude towards the use of computer related learning than faster learners. It was hypothesized that there is no significant difference between slow and below average learners and fast learners. The null hypothesis was rejected and the research hypothesis was retained. The finding of this study revealed that slower learners have a less positive attitude towards the use of computer related learning facilities than faster learners. This finding is consistent with Bruner's constructivists' theory (1986). According to this theory, learning is an active process in which learners construct new ideas or concepts based upon their current or past knowledge. In using computers in learning students are encouraged to discover principles by themselves. The curriculum is organized in a special manner so that the students continually build upon what they have already learned. These different learners in relation to their intellectual abilities had different attitudes towards the use of computer related learning facilities because they continually build upon what they have already learned.

The finding is that slower learners have a less positive attitude towards the use of computer related learning facilities than faster learners. These different learners in relation to their intellectual abilities had different attitudes towards the use of computer related learning facilities because they continually build upon what they had already learned. 


\section{RECOMMENDATIONS}

The world is advancing rapidly in technology and computers are becoming more a part of everyday life. For students are to adopt computer technologies, they must have the right attitude towards computers. Schools have the responsibility of preparing this generation for life. Schools which neglect this essential discipline are actually placing their students, teachers and administrators at great disadvantage in a new world order. The use of computer related learning facilities has so many advantages. After a careful examination of the findings of this study, the following recommendations are made

Students should be given verbal encouragement which will help them to overcome self-doubt.

Teachers should encourage student to use computers in a wide range of contexts; allowing for creativity in projects, so that all the students can pursue tasks that interest them.

Students should be motivated. According to Shih and Gamon (2001), motivation influences how and why people learn as well as how they perform. Student motivation seems to play a very important role in the learning process. Students use motivational strategies to cope with the stress and emotions that are generated when they try to overcome failures and become good learners.

Teachers should develop a positive computer culture. They should establish clear set of rules and behaviour for using computers. They need to emphasize a cooperative, supportive atmosphere. This will improve the attitude of slow learners towards computers.

Teachers should encourage students to become active learners by providing opportunities for them to reflect on their motivation and use of motivational strategies in learning. This will help assure student success in web-based instruction.

\section{REFERENCES}

1. Alessi, S.M. \& Trollip, S.R. (2001). Multimeditor learning ( $3^{\text {rd }}$ Ed002E). Massachusetts: Allyn and Bacon.

2. Amin, M.E. (2005). Social science research: Conception, methodology and analysis. Kampala Uganda: Makerere University Printers.
3. Ayodele, M.E. (2000). An introduction to research methods and analysis. Kampala, Makerere University Printery.

4. Bingimlas, K.A. (2009). Barriers to the successful integration of ICT in teaching and learning environments: A review of the literature. Eurasia Journal of Mathematics science and Technology Education 5(3), 235-245. Australia. Retrieved from http: www.education au.edu.au/jahia/webdav/sit/myjahiasite

5. Brakel, P.A. \& Chisenga, J. (2003). Impact of ICT based distance learning: The African story. The Electronic Library. 21(5), 476-486.

6. Capel, S., Leak, M, \& Turner, T. (2001). Learning to teach in the secondary school $\left(2^{\text {nd }}\right.$ ed). New Fetter Lane: Rutledge.

7. ERNWACA - Cameroon (2005). Integration of Communication Technology in Education in Central and West Africa: A case study of Pioneer Schools in Cameroon. Yaounde, Cameroon: ERNWACA - Cameroon.

8. Fraenkel, J.R. \& Wallen, N.E., (2000). How to design \& evaluate research in education. Boston: McGraw-Hill.

9.ר Long, L. \& Long, N. (2005). Computers information technology in perspective. Uppersaddle River, New Jersey: Pearson Prentice Hall.

10. Mattson, E. (2006). Field-Based models of primary teacher training. Case studies of student support systems from sub-Saharan Africa. United Kingdom: International Research Foundation for Open Learning.

11. Mbangwana, M.A. (2008). Introduction of ICT in schools and classrooms in Cameroon. K.Toure, T.M.S. Tchombe \& Karsenti (Eds), ITC and changing mindsets in education. Bamenda, Cameroon: Langaa; Bamako, Mali: ERNWACA.

12. Mikropoulos, Katsikis, A., Nikolou, E. \& Tsakalis, P. (2003). Virtual environments in biology teaching. Journal of Biological Education, 37,176-181.

13. Nwagwu, W.E. (2006). Integrating ICTs into the globalization of the poor developing countries. Information Development 22(3): 167-179.

14. Pillai, P. (2011). Uses of computers. 
15. Petty, G. (2004).Teaching today: A practical guide. United Kingdom: Nelson Thornes Ltd.

16. République du Cameroun (2007c). Stratégie nationale de développement des technologies de l'information et de la communication. Yaoundé, Cameroun : Agence nationale des technologies de l'information et de la communication (ANTIC). From

www.observatoiretic.org/documents/show/87.

17. Sam, H. K., Othman, A.E.A. and Nordin, Z. S. (2005). Computer self-efficacy, computer anxiety, and attitudes towards the internet. A study among undergraduates in Unimas. Eduational Technology and Society, 8 (4), 205-219.

18. Shelly, G.B., Cashman, T.J. and Vermaat, M.E. (2006). Discovering computers. A gateway to information. USA: Thomson Course Technology.

19. Shih, C-C. and Gamon, J. (2001).Web-Based Leaning: Relationships among student motivation, attitude, learning styles, and achievement. Journal of agricultural education. Volume 42, Issue 4, 2001.
20. Singh, K.D. (2009). Computers in Education

21. UNESCO (2002). Information and communication technology in education. Teacher Development. France (Division of Higher Education UNESCO).

22. UNESCO. (2003). Developing and using indicators of ICT use in education. From htt://www.unescobkk.org/ips/ebooks/document/IC $\mathrm{t}$ indicators. PDF.

23. Usun, S. (2004). Undergraduate students' attitudes on the use of computers in Education. The Turkish Online Journal of Educational TechnologyTOJET April 2004. ISSN: 1303-6521 volume 3 Issue 2 Article 10.

24. Williams, J. (2003). Computers and project-based learning. www.media-methods.com.

25. Yusuf, M.O. (2005). Information and communication education: Analyzing the Nigerian national policy for information technology. Instructional Education Journal 6(3), 316-321. 